\title{
How Can Firms Effectively Use Technology in Customer Journey Management William Boscardini Helouani
}

\author{
" Everyone from the CEO down to the contact center agent should know what it feels like to \\ be a customer." "
}

Blake Morgan

Keynote speaker, best-selling author \& futurist

\begin{abstract}
Customer Journey (CJ) mapping offers a view of the Customer Experience (CX) from a customer's standpoint, which acts as the first step towards a myriad of actions that can be performed to improve CX. While CJ mapping has proven to be helpful in a wide range of use cases, companies still struggle to apply technology to make it effective. This research performs a literature review to identify how IT and digital assets can be used in the CJ context, providing practical examples for organizations willing to implement a consumer-centered IT strategy. As a result, it was found that IT can be used in three primary contexts for CJ: mapping, enabling, and monitoring.
\end{abstract}

\section{Introduction}

As societies and markets are being continually transformed by digital technologies, the workaround where the customer is found has become complex, going through multiple ordering channels, interactions, advertisements, and influences, with a mixture of both physical and digital touchpoints. Under this reality, organizations rely on a digital transformation to enable customer-centricity and improve customer experience (Columbus, 2020). A recent study estimated that $55 \%$ of organizations with high digital maturity focus on digital transformation to create a unified customer experience (Gurumurthy et al., 2020).

The restrictions imposed by the Covid-19 pandemic have impacted the Consumer Journey (CJ), pushing organizations to quickly adapt by embedding digital-led experiences to overcome limitations on even simple activities, such as going out to a grocery store or dining in a restaurant (Diebner et al., 2020). Organizations need a Total Experience (TX) strategy to continuously enhance their Customer Experience (CX) and Employee Experience (EX), especially while these interactions become more digital, mobile, and distributed (Wong et al., 2021). CJ mapping is the first step toward improving the TX by identifying how their CX currently looks and where it can be improved.

A global Gartner research assessing companies that have mapped their CJ revealed that for $54 \%$ of them, their artifacts became wall art, as they failed to create digital services and IT developments that improved customer experience (Chiu \& Daigler, 2019a). Moreover, firms expect from technology a $360^{\circ}$ view of the purchase stages in order to identify which stage of the journey each customer is on, with all the many variables involved, thereby creating abstract and unrealistic expectations (Davis et al., 2019).

Academic and business literature has explored CJ and CX topics through a myriad of use cases within marketing and service research perspectives. A recent study around methodology used on 143 CX research papers revealed that they rely on surveys $(31.15 \%)$ and conceptual models $(20.28 \%)$, with very few practical implications (De Keyser et al., 2020). Although a vast majority of CJ research cites technology broadly (as in Hamilton et al., 2020; Nam \& Kannan, 2020) or specifically (as in Graves et al., 2019; McColl-Kennedy et al., 2019; Campbell et al., 2020), the literature still lacks a practical information systems approach that could handle the emerging CJ challenges currently amplified by Covid-19.

The present research study summarizes the results of a literature review to identify how IT and digital assets can be effectively used in CJ efforts by organizations. It extracts valuable insights from 33 unique CJ-focussed articles that directly cite technology, the context used, the enabler technologies, and their role on CJ management. The summary of insights will be relevant 


\section{How Can Firms Effectively Use Technology in Customer Journey Management}

\section{William Boscardini Helouani}

to organizations engaged in customer-centric digital transformation by helping them to develop a clear view on the drivers for technology usage in $\mathrm{CJ}$.

In the next section, we discuss the interface between the $\mathrm{CJ}$ and technology, including open questions relevant to the theme. The focus is on three main themes identified in the literature review: how technology can map, enable, and monitor the journey. In discussing the results, we determine which technologies are related to each use case and provide practical examples, contributing to the formulation of a digital strategy that focuses on the development of CX capabilities.

\section{Summary of insights from the literature review}

The CJ term emerged from customer experience research as a way to represent a set of steps the customer needs to take towards product or service consumption (Tax et al., 2013). Those steps are referred to as "touchpoints" in most related literature and include which actions, feelings, and connections the customer goes through regarding pre-consumption, consumption, and post-consumption (Lemon \& Verhoef, 2016). Information systems literature was the first to adopt the term in early 2011 (Teixeira et al., 2011), followed by a wide range of use case studies among business and marketing research.

The derivative term "consumer journey" $(\mathrm{CJ})$ is used in the same context as the "customer journey". However, the term "consumer" is more likely to be used in a retail scope, while "customer" is used for a broader range of services and $\mathrm{B} 2 \mathrm{~B}$ relationships.

\subsection{Customer Journey Touchpoints}

The main activity of CJ mapping is to identify a timeline view of all customer experience events during the purchase process (Rosenbaum et al., 2017). The literature refers to touchpoints as events on the CJ timeline, including moments the customer interacts with a company, as well as their actions, decisions, and feelings.

Touchpoints are organized in three customer experience stages: pre-purchase, purchase, and post-purchase. The pre-purchase stage begins from recognizing a necessity, searching for a solution, and considering buying (De Keyser et al., 2020). Purchase touchpoints include customer interactions with a company during the purchase event, such as choosing the product, purchasing and paying for it, and considering the overall environmental conditions, both physical and digital. The post-purchase stage includes customer interaction with the product, service, or company after the order itself. It includes behaviours such as usage, brand engagement, and after-sales services (Lemon \& Verhoef, 2016). Previous consumption experiences generate a general background for the consumer before starting the CJ, which also influences future experiences.

\subsection{Customer Journey Use Cases}

CJ mapping is revealed to be a powerful resource for a wide range of business perspectives. The CX may differ significantly across global markets, even within the same niche. Through CJ analysis, organizations can adapt their regional go-to-market strategy, identifying local cultural aspects, the level of technology adoption, local regulations, and competitors, among others (Nam \& Kannan, 2020).

Customer decisions throughout the CJ may be influenced directly or indirectly by others, known as "traveling companions" (Hamilton et al., 2020). Individually or aggregated, traveling companions affect several stages of the CJ, including driving motivation, offering information, and evaluating the decision process. Simultaneously, traveling companions are also influenced during the CJ according to customer feedback and experience. To have a correct understanding of the influence that travelling companions may have during the $\mathrm{CJ}$ is key to an organization's CX design.

As technology adoption to drive marketing strategies intensifies, the amount of data marketing professionals must deal with might become overwhelming. CJ mapping is identifed as an effective tool to teach datadriven marketing discipline, providing a link between theory and practice around CX (Micheaux \& Bosio, 2019).

\subsection{Customer Journey and IS Alignment}

The term "customer journey" was first used in the scientific literature when Teixeira and colleagues (2011) presented a design model for service systems within a human-computer research scope. While not attributing a definition for $\mathrm{CJ}$, their research gave a relevant foundation for the topic, introducing what they called Customer Experience Modeling as a new way to represent and evaluate customer experiences through a systematized view to guide service design and developments. 


\section{How Can Firms Effectively Use Technology in Customer Journey Management}

\section{William Boscardini Helouani}

The first attribution of a CJ definition, as provided by Kankainen and colleagues (2012), referred to CJ as "one of the concepts applied in service design to emphasize and define the process". To support the definition, they also highlight the CJ objective to use a client's perspective to identify and describe different touchpoints in the CX.

CJ was put at the center of the "service delivery network" concept in the human-computer field, which explains how two or more companies can offer services together while presenting themselves through a single brand from a customer perspective (Tax et al., 2013). In addition to a solid foundation for the CJ, Tax and colleagues (2013) contributed a wide range of future research questions on the topic related to various business perspectives, such as strategic capabilities, customer co-creation, C2C interactions, customer relationships management, and service success.

CJ mapping is appropriate for designing user interfaces and a valuable tool for firms looking for CX improvements. Introducing $\mathrm{CJ}$ as a marketing discipline, Lemon and Verhoef (2016) highlighted its relevance as omnichannel became the new standard, where customers rely on several touchpoints in their consumption process. The higher the number of touchpoints a CJ may have, the less control over the experience the firm possesses.

Along with an overview of marketing theory related to consumer experience, Lemon and Verhoef (2016) created a research agenda for the $\mathrm{CJ}$ topic, suggesting its analysis through several prisms: drivers for customer experience, CJ mapping, multidevice and mobile journey, customer experience measurement, experience design, and from an internal organization perspective. Among the 35 proposed research questions, eight directly involves the information systems field. While the questions remain unanswered, they nevertheless offer a significant contribution to this research.

Information technology also constitutes a key to digitalizing service-only journeys through connecting and enabling new service encounters. A "service encounter" is a touchpoint in the CJ that includes a service experience perspective (Voorhees et al., 2017). The stages of a CJ may be classified as pre-core, core, and post-core service encounters when viewed from a service prism. Voorhees and colleagues (2017) identified 35 new research questions around service experience, from which eight directly include technology.
From a more recent standpoint, De Keyser and colleagues (2020) also pointed out relevant research questions around information systems and CJ while reviewing 143 publications about CX. Although some of the previous questions remain unanswered, some of the more complex ones were raised. A comprehensive list of information systems-related questions around CJ can be found in Table 1, summarizing the main business research concerns.

\section{Methodology}

The current research performs a systematic literature review to identify multiple expectations from adopting IT assets and capabilities in CJ management from a business perspective. To create a replicable and transparent process in the literature analysis, we used a framework proposed by Ali and Usman (2018).

First, we sourced articles within the Web of Science research index platform, applying the filters "Customer Journey OR Consumer Journey." We filtered the 235 results to articles published in journals, excluding books and conference materials, which resulted in a total of 144 different pieces. Then, we used technology-related keywords to refine the search results and identify relevant articles for this research. The complete list of search terms and identified articles is displayed in Table 2.

After removing duplicate results that represented articles citing more than one keyword, the total number of evaluated research articles was reduced to 47 . Finally, the context in which such technologies are mentioned was extracted and grouped according to qualitative similarities, summarizing the primary application purpose. During the qualitative analysis, 14 articles were identified that mentioned technology outside of the CJ context, which were thus excluded from further consideration. This additional reduction resulted in 33 articles that served as the foundation for this research.

\section{Key Findings and Discussion}

The research found three main drivers for technology adoption in the CJ context: mapping, enabling, and monitoring the journey. First, it was pointed out by 7 of the 33 evaluated articles that technology is fundamental in mapping the journey itself, from which the current experience and different persona CJs emerge. Once the mapping is done, the technology enables the journey through digital assets that serve as touchpoints, giving 


\section{How Can Firms Effectively Use Technology in Customer Journey Management} William Boscardini Helouani

Table 1. Open questions around Customer Journey with potential information systems contribution

\begin{tabular}{l} 
Open Questions \\
\hline How can different sources of data (e.g., surveys, operational data, social media) be \\
linked to further elucidate the formation of CX? \\
How can touchpoints be seamlessly integrated across the CJ (similar to channel \\
integration)? What models will enable firms to accomplish such integration? \\
How can brands exert more control over non-"owned" touchpoints? Can such \\
touchpoints be turned into brand-owned touchpoints? At which stages of the \\
journey?
\end{tabular}

How does the use of multiple devices across the journey influence CX and customer behaviours?

How can we capture CX data in situ? How can we capture and analyze the raw components of CX without influencing the customer journey or experience?

How can we incorporate new data and analytics into CX analysis (e.g., social listening, text, photo and video analytics, location-based data) to further understand CX and the customer journey?

Can machine learning models be used to analyze the customer purchase journey and identify opportunities for intervention and influence?

How can firms effectively use technology in CX management?

What is the role of technology in value creation during different encounters?

How can mobile technologies, the Internet of Things, and cloud-based systems enable the creation of seamless customer experiences across the encounters?

How should the interfaces between the core and the other encounters be designed to improve coordination?

How can relevant customer information be captured and shared across encounters?

How can information available in social media about the pre- and post-core be used to design and deliver the core?

Lemon \& Verhoef

(2016)

Voorhees et al.

(2017)

How can the information generated by the Internet of Things and smart services in the core be employed to trigger and customize the post-core encounter?

What are the unique effects of service failures caused by customers while using selfservice technologies?

What is the impact of deviant consumer behaviour in online communities?

How different is CX in multi-actor settings, such as sharing platforms?

How do rapid automation and microtargeting practices along with the $\mathrm{CJ}$ impact CX?

How can contextual data influence CX strategies and inform new business models?

In what way(s) can brands/firms systematically make use of contextual insights to enhance CX?

How far can brands/firms go in using contextual data to personalize CX?

How do the various dimensions work in combination? 


\section{How Can Firms Effectively Use Technology in Customer Journey Management}

William Boscardini Helouani

Table 2. Research Keywords and Related Articles

\begin{tabular}{|c|c|c|c|}
\hline Type & Code & Keyword & Articles \\
\hline \multirow{3}{*}{ IS Topic } & IS01 & Information Systems & 4 \\
\hline & IS02 & $\begin{array}{l}\text { Information } \\
\text { Technology }\end{array}$ & 14 \\
\hline & IS03 & Digital & 22 \\
\hline \multirow{5}{*}{ Technologies } & T001 & Platform & 14 \\
\hline & T002 & Big Data & 5 \\
\hline & T003 & Artificial Intelligence & 6 \\
\hline & T004 & Machine Learning & 2 \\
\hline & T005 & Internet of Things & 1 \\
\hline
\end{tabular}

customers physical access to specific touchpoints, helping customers advance in their journey, and personalizing the experience. "Enabling" is the most used context where technology relates to CJ, appearing in 29 articles. Finally, technology can also monitor the whole CJ, both from a specific customer point of view and with a broader perspective on CX performance, as stated in 14 articles. The monitoring phase proved to be crucial to generate improvements on the journey, and once any touchpoint is changed, the map must also be updated.

From each analyzed article, we extracted the specific context in which IT can be applied to CJ management and the technologies used to achieve it. Moreover, it was observed whether the technology was applied to map the CJ, enable touchpoints, or monitor it. Table 3 shows the key outcomes from the literature review.

\subsection{Customer Journey Mapping}

The first step in improving CX throughout the CJ is to perform a touchpoints mapping. This mapping is often performed manually through cardboards during a physical workshop with around 12 people from different company areas (Chiu \& Daigler, 2019b). Still, it only gives a static vision of the journey that might become quickly obsolete. Following the CJ approach's popularization, several specialized mapping software options emerged,

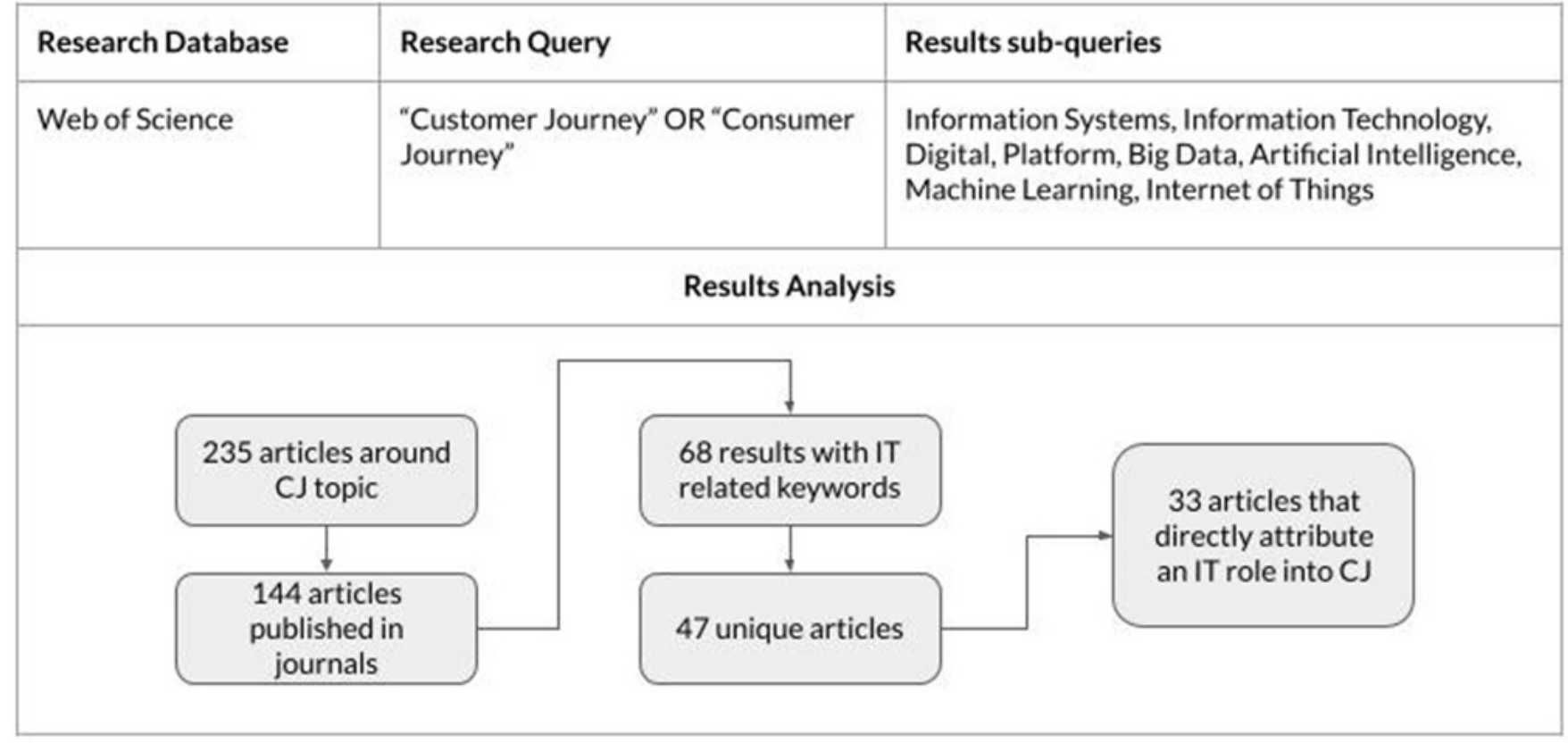

Figure 1. Research stages and results 


\section{How Can Firms Effectively Use Technology in Customer Journey Management}

\section{William Boscardini Helouani}
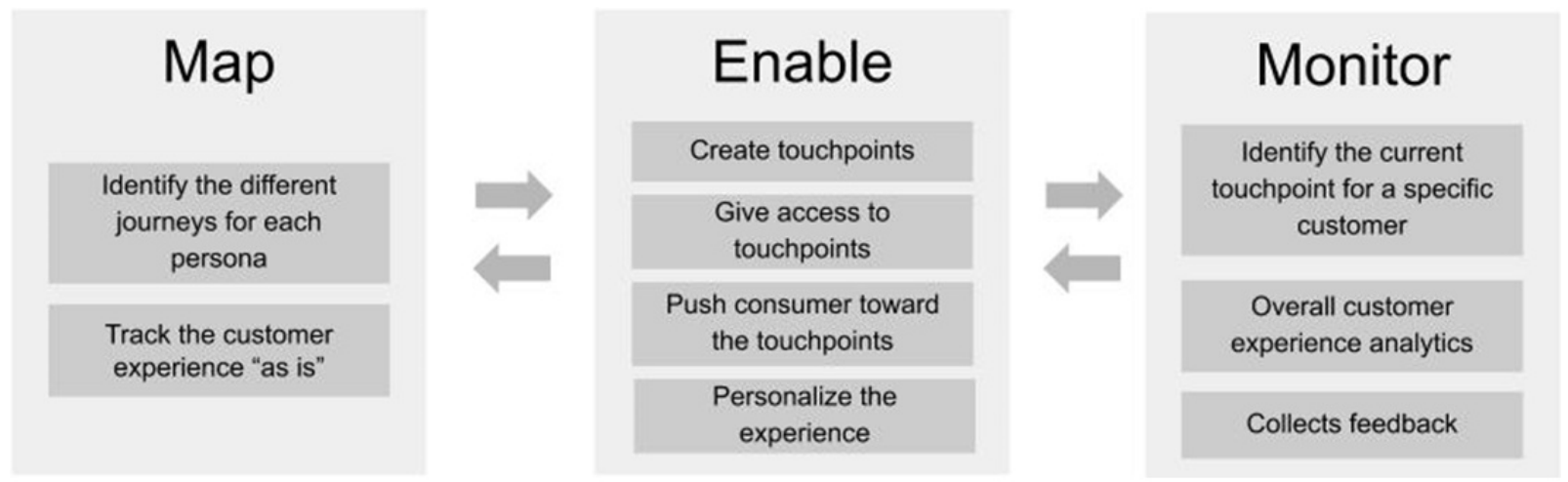

Figure 2. Drivers for technology usage in Customer Journey

usually offered as a service (SaaS).

Ramshaw (2016) performed a complete review of CJ mapping software, which evaluated 12 different digital tools to create maps. He suggested that enterprises should use a tool to do the initial mapping and manage its process improvement, which would be achieved by software such as UX360, Visual Paradigm, and SuiteCX. For small and mid-sized companies that cannot afford or do not need the power of such corporate solutions, a reasonable basic option could start with Microsoft PowerPoint or Microsoft Visio. Once the company gets some practical experience and needs to use CJ mapping as a living document, they can migrate to Smaply or Touchpoint Dashboard. Smaply has also proven to be valuable in teaching $\mathrm{CJ}$ as a marketing subject, thus bringing potential for more familiarity among marketing professionals (Micheaux \& Bosio, 2019).

Even though identifying touchpoints could be an empirical activity, collecting data on such matters is highly recommended. One of the most popular software to analyze CJ data is Google Analytics, which is useful for exploring consumer behaviour based on digital properties with a simplified view. Dimensions that can be extracted through Google Analytics that help the composition of $\mathrm{CJ}$ mapping include the behaviour flow of customer clusters, the customer life cycle, and individual data model view (Google, 2018). Identifying the different flows that a population of users with a particular digital property go through might help to lighten the pain points throughout the journey. Moreover, life cycle analysis offers a promising direction about how long a customer takes to move forward with each touchpoint. Taking the viewpoint of an individual customer allows understanding an outlier's behaviour in the journey. Although valuable, Google Analytics might offer a too simplistic view regarding CJ, as it lacks qualitative data to create decision-ready information (Terragni \& Hassani, 2018).

Among other popular alternatives to analytics, Hotjar and Smartlook stand out for offering more in-depth insights through various data-gathering approaches (Filip \& Čegan, 2019). By observing real-life customer interaction with digital properties, one can figure out patterns representing a larger population, and thus gain better insights into needed solutions. Customer feedback through page surveys and widgets is also a valuable source of data for CJ mapping, seeding the map with customer thoughts and feelings.

\subsection{Enabling the Consumer Journey}

Digital technologies have significantly changed the way customers engage with brands and effectively make a consumption decision. CJs that do not have at least a few digital-influenced touchpoints are rare, and there always seems to be room available for more digitization. It might be a digital asset that provides information to consumers around their needs or that enables a transaction itself, such as institutional websites or ecommerce. It could be devices from which the customer identifies a particular store location or compares alternatives, a remarketing advertisement through a social network to remind the consumer to come back to the $\mathrm{CJ}$, or even adapting a provided service to better match customer needs. Research has revealed that technology enables touchpoints in four main areas: creating digital touchpoints themselves, giving access to touchpoints, pushing the consumers toward the CJ, and personalizing the consumer experience.

\section{Create touchpoints}

Organizational digital properties are technology-enabled 


\section{How Can Firms Effectively Use Technology in Customer Journey Management} William Boscardini Helouani

Table 3. Technology applications around Customer Journey

\begin{tabular}{|c|c|c|c|c|c|}
\hline Authors & IT Usage Context & $\begin{array}{l}\text { Enabler } \\
\text { Technologies }\end{array}$ & Map & $\begin{array}{l}\text { CJ Drive } \\
\text { Enable }\end{array}$ & $\begin{array}{l}\text { er } \\
\text { Monitor }\end{array}$ \\
\hline $\begin{array}{l}\text { (Klein et al., } \\
\text { 2020) }\end{array}$ & $\begin{array}{l}\text { Map the consumer journey; } \\
\text { Gather individual data along } \\
\text { with CJ; Manage the bottom- } \\
\text { line communication } \\
\text { performance }\end{array}$ & $\begin{array}{l}\text { CJ Mapping } \\
\text { Software; Social } \\
\text { Network; Data } \\
\text { Analytics; }\end{array}$ & $\mathrm{X}$ & & \\
\hline $\begin{array}{l}\text { (Mosquera et al., } \\
\text { 2018) }\end{array}$ & $\begin{array}{l}\text { Analyze } \mathrm{CJ} \text { through an } \\
\text { omnichannel perspective; } \\
\text { improve the in-store } \\
\text { experience; }\end{array}$ & $\begin{array}{l}\text { In-store } \\
\text { technologies; E- } \\
\text { commerce; }\end{array}$ & & $\mathrm{X}$ & $\mathrm{X}$ \\
\hline $\begin{array}{l}\text { (Cortinas et al., } \\
\text { 2019) }\end{array}$ & $\begin{array}{l}\text { Explore the CJ from a deeper } \\
\text { customer's perspective; }\end{array}$ & $\begin{array}{l}\text { IoT; Eye- } \\
\text { tracking } \\
\text { software; }\end{array}$ & & $\mathrm{X}$ & \\
\hline $\begin{array}{l}\text { (De Bellis \& } \\
\text { Venkataramani } \\
\text { Johar, 2020) }\end{array}$ & $\begin{array}{l}\text { Let customer advance } \\
\text { towards the CJ through } \\
\text { autonomous shopping } \\
\text { software; }\end{array}$ & $\begin{array}{l}\text { AI; Virtual } \\
\text { Assistants; } \\
\text { Robots; Drones; } \\
\text { Autonomous } \\
\text { Shopping } \\
\text { Systems; }\end{array}$ & & $\mathrm{X}$ & \\
\hline (Wang, 2020) & $\begin{array}{l}\text { Increase customer's brand } \\
\text { engagement and loyalty on } \\
\text { the } C J \text { through mobile apps; }\end{array}$ & $\begin{array}{l}\text { Mobile; Apps; } \\
\text { CRM; }\end{array}$ & & $\mathrm{X}$ & \\
\hline $\begin{array}{l}\text { (Tupikovskaja- } \\
\text { Omovie \& Tyler, } \\
\text { 2020) }\end{array}$ & $\begin{array}{l}\text { Segment customers on the } \mathrm{CJ} \\
\text { through eye-tracking } \\
\text { analytics; }\end{array}$ & $\begin{array}{l}\text { E-commerce; } \\
\text { Eye-tracking } \\
\text { system; } \\
\text { Artificial } \\
\text { Intelligence; }\end{array}$ & & $\mathrm{X}$ & \\
\hline $\begin{array}{l}\text { (Kaczorowska- } \\
\text { Spychalska, } \\
\text { 2017) }\end{array}$ & $\begin{array}{l}\text { Increase the customer's } \\
\text { awareness, abilities, and } \\
\text { requirements through the CJ; } \\
\text { Performs a multidimensional } \\
\text { analysis of online and offline } \\
\text { data; }\end{array}$ & $\begin{array}{l}\text { Mobile; E- } \\
\text { commerce; } \\
\text { Cloud } \\
\text { Computing; AI; } \\
\text { IoT; Big Data; }\end{array}$ & & $\mathrm{X}$ & $\mathrm{X}$ \\
\hline $\begin{array}{l}\text { (Micheaux \& } \\
\text { Bosio, 2019) }\end{array}$ & $\begin{array}{l}\text { Improve the CJ with data; } \\
\text { Map the consumer journey; }\end{array}$ & $\begin{array}{l}\text { Data } \\
\text { Management } \\
\text { Platform, Data } \\
\text { Lake, CJ } \\
\text { Mapping } \\
\text { Software }\end{array}$ & $\mathrm{X}$ & $\mathrm{X}$ & $\mathrm{X}$ \\
\hline
\end{tabular}




\section{How Can Firms Effectively Use Technology in Customer Journey Management}

William Boscardini Helouani

Table 3. Technology applications around Customer Journey (cont'd)

\begin{tabular}{|c|c|c|c|c|c|}
\hline $\begin{array}{l}\text { (Graves et al., } \\
\text { 2019) }\end{array}$ & $\begin{array}{l}\text { Control the billing according } \\
\text { to the origin and destination; } \\
\text { Live CJ monitoring; Metrics; }\end{array}$ & IoT; Big Data; & & $\mathrm{X}$ & $\mathrm{X}$ \\
\hline $\begin{array}{l}\text { (Nyström \& } \\
\text { Mickelsson, } \\
\text { 2019) }\end{array}$ & $\begin{array}{l}\text { Supports the delivery of the } \\
\text { suitable advertisement for } \\
\text { the customer during the CJ, } \\
\text { leveraging the value- } \\
\text { creation; }\end{array}$ & $\begin{array}{l}\text { Automated } \\
\text { Systems; } \\
\text { Machine } \\
\text { Learning; AI; } \\
\text { Advertising } \\
\text { Platforms; } \\
\end{array}$ & & $\mathrm{X}$ & \\
\hline $\begin{array}{l}\text { (Nam \& Kannan, } \\
\text { 2020) }\end{array}$ & $\begin{array}{l}\text { Enhance the engagement } \\
\text { level at CJ; Track touchpoint } \\
\text { contribution to the purchase } \\
\text { conversion; }\end{array}$ & $\begin{array}{l}\text { Wearables; } \\
\text { Mobile; Social } \\
\text { Media; AI; IoT; } \\
\text { Virtual Reality; } \\
\text { Augmented } \\
\text { Reality; }\end{array}$ & & $\mathrm{X}$ & $\mathrm{X}$ \\
\hline $\begin{array}{l}\text { (Damnjanović et } \\
\text { al., 2020) }\end{array}$ & $\begin{array}{l}\text { Engage with the consumer on } \\
\text { every touchpoint; Provide } \\
\text { opportunities to create } \\
\text { personalized experiences; }\end{array}$ & $\begin{array}{l}\text { Mobile; Cloud; } \\
\text { AI; Blockchain; } \\
\text { IoT; AR; VR; }\end{array}$ & & $\mathrm{X}$ & \\
\hline (Kim et al., 2020) & $\begin{array}{l}\text { Track the consumer towards } \\
\text { the CJ; }\end{array}$ & $\begin{array}{l}\text { Data Analytics; } \\
\text { Digital } \\
\text { Platform; Social } \\
\text { Network; } \\
\end{array}$ & $\mathrm{X}$ & & $\mathrm{X}$ \\
\hline $\begin{array}{l}\text { (Marino \& Lo } \\
\text { Presti, 2019) }\end{array}$ & $\begin{array}{l}\text { Helps consumer to move } \\
\text { forward the CJ through } \\
\text { enabling communication } \\
\text { between him and the brand; } \\
\text { Gets customer feedback; }\end{array}$ & $\begin{array}{l}\text { Mobile Instant } \\
\text { Messages; CRM; } \\
\text { Social } \\
\text { Networks; }\end{array}$ & & $\mathrm{X}$ & \\
\hline (Matsuoka, 2020) & $\begin{array}{l}\text { Enables personalization on } \\
\text { the CJ; Allows firms to build } \\
\text { customer relationships; } \\
\text { Increase revenues; }\end{array}$ & Big Data; & & $\mathrm{X}$ & $\mathrm{X}$ \\
\hline $\begin{array}{l}\text { (Grewal \& } \\
\text { Roggeveen, } \\
2020 \text { ) }\end{array}$ & $\begin{array}{l}\text { Influence consumer decision } \\
\text { process along with the } \mathrm{CJ} \text {; } \\
\text { Provide personalization; }\end{array}$ & $\begin{array}{l}\text { Mobile; AI; IoT; } \\
\text { In-store } \\
\text { technologies; } \\
\text { Social Network; } \\
\text { 3D Printing; }\end{array}$ & & $\mathrm{X}$ & \\
\hline $\begin{array}{l}\text { (Campbell et al., } \\
\text { 2020) }\end{array}$ & $\begin{array}{l}\text { Predict customer demands } \\
\text { on the CJ; Assist employees } \\
\text { on serving customers; } \\
\text { Provide insights about the } \\
\text { customers; Engage with } \\
\text { customers; Conduct ROI }\end{array}$ & $\begin{array}{l}\text { Artificial } \\
\text { Intelligence; } \\
\text { Machine } \\
\text { Learning; Big } \\
\text { Data; }\end{array}$ & $\mathrm{X}$ & $\mathrm{X}$ & $\mathrm{X}$ \\
\hline
\end{tabular}




\section{How Can Firms Effectively Use Technology in Customer Journey Management}

William Boscardini Helouani

Table 3. Technology applications around Customer Journey (cont'd)

\begin{tabular}{|c|c|c|c|c|c|}
\hline & $\begin{array}{l}\text { analysis; Analyse and map } \\
\text { the CJ; Segment customers; } \\
\text { Generate insights for strategy } \\
\text { definition, pricing, channels, } \\
\text { logistics, and communication; }\end{array}$ & & & & \\
\hline $\begin{array}{l}\text { (Steward et al., } \\
\text { 2019) }\end{array}$ & $\begin{array}{l}\text { Enables the mapping and } \\
\text { modeling of CJ; Assess the } \\
\text { buying process and its } \\
\text { consequences through data } \\
\text { analytics; }\end{array}$ & $\begin{array}{l}\text { Big Data; } \\
\text { Analytics } \\
\text { Software; }\end{array}$ & $\mathrm{X}$ & $\mathrm{X}$ & \\
\hline $\begin{array}{l}\text { (McColl-Kennedy } \\
\text { et al., 2019) }\end{array}$ & $\begin{array}{l}\text { Gain insights around pain } \\
\text { points along with the CJ; } \\
\text { Extract rich insights; Identify } \\
\text { root causes; Uncover hidden } \\
\text { risks; capture customer's } \\
\text { emotional and cognitive } \\
\text { responses; Spot and prevent } \\
\text { decreasing sales; Prioritize } \\
\text { actions to improve CX; }\end{array}$ & $\begin{array}{l}\text { Text mining; } \\
\text { Big Data; }\end{array}$ & $\mathrm{X}$ & $\mathrm{X}$ & $\mathrm{X}$ \\
\hline (Sperkova, n.d.) & $\begin{array}{l}\text { Collect customer sentiment } \\
\text { and feedback; Generate } \\
\text { insights to improve CJ; }\end{array}$ & $\begin{array}{l}\text { CRM; BI; Data } \\
\text { Mining; } \\
\text { Customer } \\
\text { Review } \\
\text { Software; } \\
\end{array}$ & & & $\mathrm{X}$ \\
\hline $\begin{array}{l}\text { (Wilson-Nash et } \\
\text { al., 2020) }\end{array}$ & $\begin{array}{l}\text { Offers contactless } \\
\text { touchpoints in customer } \\
\text { service through social bots, } \\
\text { preferred by young adults; } \\
\text { Provides an opportunity to } \\
\text { firms to meet consumer } \\
\text { needs during the CJ; Enhance } \\
\text { segmentation and target } \\
\text { marketing; }\end{array}$ & $\begin{array}{l}\text { Artificial } \\
\text { Intelligence, } \\
\text { Chatbots, Social } \\
\text { Networks; }\end{array}$ & & $\mathrm{X}$ & \\
\hline $\begin{array}{l}\text { (Mosquera et al., } \\
\text { 2017) }\end{array}$ & $\begin{array}{l}\text { Generates new touchpoints } \\
\text { in the CJ through mobile; }\end{array}$ & Mobile; Wifi; & & $\mathrm{X}$ & \\
\hline (Inversini, 2017) & $\begin{array}{l}\text { Enables meaningful } \\
\text { relationships between the } \\
\text { customer and the company } \\
\text { throughout the CJ; }\end{array}$ & $\begin{array}{l}\text { Mobile; Self- } \\
\text { service kiosks; } \\
\text { Social Network; }\end{array}$ & & $\mathrm{X}$ & \\
\hline $\begin{array}{l}\text { (George \& } \\
\text { Wakefield, 2018) }\end{array}$ & $\begin{array}{l}\text { Identify the touchpoints from } \\
\text { a CJ; Forecast the consumer's } \\
\text { churn during the CJ based on } \\
\text { behavioural data; }\end{array}$ & Big Data & $\mathrm{X}$ & & $\mathrm{X}$ \\
\hline
\end{tabular}




\section{How Can Firms Effectively Use Technology in Customer Journey Management} William Boscardini Helouani

Table 3. Technology applications around Customer Journey (cont'd)

\begin{tabular}{|c|c|c|c|c|}
\hline $\begin{array}{l}\text { (Hu \& Tracogna, } \\
\text { 2020) }\end{array}$ & $\begin{array}{l}\text { Enable B2B and C2C } \\
\text { touchpoints; }\end{array}$ & $\begin{array}{l}\text { E-commerce; } \\
\text { Mobile; Social } \\
\text { networks; }\end{array}$ & $\mathrm{X}$ & \\
\hline $\begin{array}{l}\text { (Lynch \& Barnes, } \\
\text { 2020) }\end{array}$ & $\begin{array}{l}\text { Enable the touchpoints on } \\
\text { the fashion retail CJ; }\end{array}$ & $\begin{array}{l}\text { Mobile; } \\
\text { Desktop; Apps; } \\
\text { Websites; Social } \\
\text { Network; }\end{array}$ & $\mathrm{X}$ & \\
\hline $\begin{array}{l}\text { (Singh et al., } \\
\text { 2020) }\end{array}$ & $\begin{array}{l}\text { Creates a unique customer } \\
\text { engagement voice in a digital } \\
\text { environment; }\end{array}$ & $\begin{array}{l}\text { Big Data; API; } \\
\text { AI; Chatbots; } \\
\text { CRM; Robotics; } \\
\text { Automation } \\
\text { Software; } \\
\text { Digital Ordering } \\
\text { System; ERP; } \\
\end{array}$ & $\mathrm{X}$ & \\
\hline $\begin{array}{l}\text { (Wagner et al., } \\
2020)\end{array}$ & $\begin{array}{l}\text { Enable the conversion } \\
\text { touchpoints on the CJ; }\end{array}$ & $\begin{array}{l}\text { App; Mobie; E- } \\
\text { commerce; }\end{array}$ & $\mathrm{X}$ & \\
\hline $\begin{array}{l}\text { (Paluch \& } \\
\text { Tuzovic, 2019) }\end{array}$ & $\begin{array}{l}\text { Gather consumer data during } \\
\text { the CJ; }\end{array}$ & Wearables; & $\mathrm{X}$ & \\
\hline $\begin{array}{l}\text { (Wozniak et al., } \\
\text { n.d.) }\end{array}$ & $\begin{array}{l}\text { Create implicit touchpoints, } \\
\text { such as online } \\
\text { advertisements; Conduct } \\
\text { explicit touchpoints, } \\
\text { including brand content and } \\
\text { reviews; Track the } \\
\text { customer's conversion; }\end{array}$ & $\begin{array}{l}\text { Mobile; } \\
\text { Websites; App; } \\
\text { Messenger; } \\
\text { Augmented } \\
\text { Reality; Virtual } \\
\text { Reality; } \\
\text { Chatbot; } \\
\end{array}$ & $\mathrm{X}$ & $\mathrm{X}$ \\
\hline $\begin{array}{l}\text { (Pallant et al., } \\
\text { 2020) }\end{array}$ & $\begin{array}{l}\text { Enable customer's co- } \\
\text { creation of the product } \\
\text { during the CJ; }\end{array}$ & $\begin{array}{l}\text { Digital } \\
\text { Platforms }\end{array}$ & $\mathrm{X}$ & \\
\hline (Dellaert, 2019) & $\begin{array}{l}\text { Enable consumer co-creation } \\
\text { of products during the CJ; } \\
\text { Collect consumer feedback; }\end{array}$ & $\begin{array}{l}\text { Digital } \\
\text { Platforms; Big } \\
\text { Data; Predictive } \\
\text { Analytics; }\end{array}$ & $\mathrm{X}$ & $\mathrm{X}$ \\
\hline $\begin{array}{l}\text { (Shen et al., } \\
\text { 2020) }\end{array}$ & $\begin{array}{l}\text { Enable several touchpoints } \\
\text { on the tourism CJ; Analyse } \\
\text { and enhance the CJ; Collect } \\
\text { tourist feedback; }\end{array}$ & $\begin{array}{l}\text { IoT; Cloud } \\
\text { computing; AI; } \\
\text { Mobile; Big } \\
\text { Data; Wifi; } \\
\text { Virtual Reality; } \\
\text { Augmented } \\
\text { Reality; } \\
\text { Chatbots; } \\
\text { Wearable; } \\
\text { devices; Beacon }\end{array}$ & $\mathrm{X}$ & $\mathrm{X}$ \\
\hline
\end{tabular}




\section{How Can Firms Effectively Use Technology in Customer Journey Management}

\section{William Boscardini Helouani}

touchpoints where customers can perform one or more stages of the CJ. The most basic application starts with non-transactional websites, which have a strategic role in informing consumers about a product or service, along with raising awareness about a specific need. Firms can use content websites with a branded or unbranded approach, which often serves as a starting point to the journey when aligned with inbound communication and Search Engine Optimization strategies (Ehrlich et al., 2017). The next level of technology-enabled touchpoints includes transactional behaviour, which enables conversions to happen with reduced friction in an omnichannel environment. This can consist of a retail e-commerce platform or a B2B web ordering application.

Mobile apps and responsive websites might play both instructional and transactional roles. Customers that interact with branded mobile applications during the consumption process increase their engagement throughout the journey, spending more on such brands than on non-engaged ones (Wang, 2020). The most common purpose of mobile apps in a CJ context is to support Customer Relationship Management (CRM) practices, activate promotions, and leverage customer loyalty. In addition to explicit mobile touchpoint opportunities, consumers also face implicit touchpoints daily that might influence the $\mathrm{CJ}$, such as reading news or accessing social media, which can be impacted by sponsored content (Wozniak et al., 2018).

Digitizing the in-store experience is also a trend in retail, with the growing adoption of technologies such as complimentary Wifi, interactive screens, virtual mirrors for fitting, self-service kiosks, and QRCode interactions, among others (Mosquera et al., 2017).

\section{Providing access to digital touchpoints}

Organizations perceive a given digital property as a single touchpoint, while at the customer level, it might be experienced with variety depending on the device the customer uses to interact with them. These devices are referred to as e-channels, which include computers, mobile devices, Smart TVs, Smart Glasses, Smart Watches, and other new devices that now emerging (Wagner et al., 2020). Wearable technology opens up a new alley of possibilities within the CJ, for example, with self-tracking incentives explored by insurance companies (Paluch \& Tuzovic, 2019).

\section{Push the consumer toward the journey}

One of the most fundamental roles technology plays in
CJs is to help customers move through their journey, accomplishing the consumption process in a trustable yet dynamic way. The journey is not the same for every customer, but instead, each one has different timings and needs (De Keyser et al., 2020). Technologies such as machine learning and artificial intelligence help segment, target, and position consumers according to data clusters (Campbell et al., 2020). A navigation footprint made by consumers on digital properties can be translated into intentions, serving as a trigger for proper impulses that an organization can push. Data Management Platforms (DMPs) and Operational Marketing Databases (OMDBs) are technology alternatives to control consumer intentions in a digital environment and generate custom audiences for advertisements (Micheaux \& Bosio, 2019). For example, suppose a particular customer navigating on the "Store Locator" page of a specific chain. In that case, its digital marketer could define a strategy to display relevant content through social media advertisements related to in-store behaviour.

Consumers often need some level of support during their journey. Organizations can use digital tools to communicate with consumers, such as mobile instant messaging apps, thereby reducing friction generated by traditional communication methods such as email and telephone (Marino \& Lo Presti, 2019). Within instant messaging, firms can use chatbots to create 24-hour first-level customer service powered by Natural Language Processing (NLP) technology, which captures user intentions based on unstructured messages (Singh et al., 2020). For creating more customer proximity, social bots can be used by organizations that simulate human behaviour in social networks, thus generating frictionless interactions (Wilson-Nash et al., 2020).

\section{Personalizing the Journey}

When a customer feels actively part of the decisionmaking process along the journey, they have greater engagement. Technology is a strong ally in various levels of personalizing the consumer experience, and supporting a sharing economy (Dellaert, 2019). Digital platforms offer product individualization via mass customization, allowing consumers to co-produce, cobuild, co-design, and co-configure (Pallant et al., 2020). In such an approach, the organization and consumer take on the product design, component selection, and assembly, and use the product together.

By focusing on improving sales conversion on ecommerce platforms, eye-tracking technology allows 


\section{How Can Firms Effectively Use Technology in Customer Journey Management}

\section{William Boscardini Helouani}

one to understand the customer's point of view and to customize the experience, generating easier-to-use interfaces (Tupikovskaja-Omovie \& Tyler, 2020). By performing an ongoing competitor analysis, dynamic pricing algorithms powered by machine learning and artificial intelligence can suggest and automatically set the most appropriate price for products and services while avoiding pricing anomalies (Campbell et al., 2020). For example, the New York bus service's electronic ticketing system controls the origin and destination of the passenger, making proportional charges to the travel duration. All data from this customization are processed via big data, which enables new customizations on the journey by identifying customer clusters that allow optimizing the service as a whole (Graves et al., 2019).

\subsection{Monitoring the Consumer Journey}

The CJ is a rich source of information for organizations seeking to make more data-driven decisions. Large volumes of data captured at different touchpoints can be processed to generate insights into specific pains in the process, including mining unstructured texts from comments and social networks (McColl-Kennedy et al., 2019). Technologies such as machine learning applied to big data allow firms to analyze the current scenario and understand the market and customer dynamics (Campbell et al., 2020).

Firms that manage to leverage data effectively through advanced analytics have a strategic marketing competitive advantage (Dellaert, 2019). An accurate analysis of the CJ must deal with the heterogeneity of journies, thus allowing an interactive view that does not reduce the user's activities to a small set of actions (Kim et al., 2020). From a practical perspective, once a company learns in which stage a particular consumer is on the journey and combines this knowledge with predictive analytics, it makes a very assertive approach.

\section{Conclusion}

By answering one of the open questions around CJ that need the contribution of information systems, the present research sought to offer companies a generalist view on how technology can be used in the context of CJs. By identifying that digital tools can play a relevant role during journey mapping, enabling touchpoints, and the overall monitoring of the journey, this research offers a direction for companies seeking to create effective initiatives to improve their CX. Digital tools play a fundamental role in CX, although many businesses have not yet assimilated the most appropriate technologies for this purpose. New opportunities therefore exist for technology firms to create easy-to-use and affordable products for $\mathrm{CJ}$ management. In addition to addressing unanswered questions found in the literature, it is also necessary to perform a detailed review at each of the identified stages of technology usage in $\mathrm{CJ}$, thereby deepening the discussion with case studies and a technical approach. 


\title{
How Can Firms Effectively Use Technology in Customer Journey Management
}

\author{
William Boscardini Helouani
}

\section{References}

Ali, N.B. \& Usman, M. 2018. Reliability of Search in Systematic Reviews: Towards a quality assessment framework for the automated-search strategy. Information and Software Technology, 99: 133-147.

DOI: https://doi.org/10.1016/j.infsof.2018.02.002

Campbell, C., Sands, S., Ferraro, C., Tsao, H.Y.J., \& Mavrommatis, A. 2020. From Data to Action: How marketers can leverage AI. Business Horizons, 63(2): 227-243.

DOI: https://doi.org/10.1016/j.bushor.2019.12.002

Chiu, M., \& Daigler, J. 2019a. How to Prevent Customer Journey Maps From Becoming Wall Art.

https://www.gartner.com/document/3942174

Chiu, M., \& Daigler, J. 2019b. How to Run a Do-ItYourself Customer Journey Mapping Workshop.

Columbus, L. 2020. Why Digital Transformation Always Needs To Start With Customers First.

https://www.forbes.com/sites/louiscolumbus/2020/

08/30/why-digital-transformation-always-needs-to-

start-with-customers-first/?

Cortinas, M., Cabeza, R., Chocarro, R., \& Villanueva, A. 2019. Attention to Online Channels Across the Path to Purchase: An eye-tracking study. Electronic Commerce Research and Applications, 36.

DOI: https://doi.org/10.1016/j.elerap.2019.100864

Damnjanović, V., Lončarić, D., \& Dlačić, J. 2020. Teaching Case Study: Digital marketing strategy of Accor hotels: Shaping the future of hospitality. Tourism and Hospitality Management, 26(1): 233-244.

Davis, M., Gillespie, P., Heudecker, N., Huang, O., Foo Kune, L., Bloom, B., Davis, K., \& Delrieu, B. 2019. Use Customer Data Management Technologies to Deliver Better Customer Experiences.

https://www.gartner.com/document/3969791

De Bellis, E., \& Venkataramani Johar, G. 2020. Autonomous Shopping Systems: Identifying and Overcoming Barriers to Consumer Adoption. Journal of Retailing, 96(1): 74-87.

DOI: https://doi.org/10.1016/j.jretai.2019.12.004

De Keyser, A., Verleye, K., Lemon, K.N., Keiningham, T.L., \& Klaus, P. 2020. Moving the Customer Experience Field Forward: Introducing the Touchpoints, Context, Qualities (TCQ) Nomenclature. Journal of Service Research. DOI: https://doi.org/10.1177/1094670520928390

Dellaert, B.G.C. 2019. The Consumer Production Journey: marketing to consumers as co-producers in the sharing economy. Journal of the Academy of Marketing Science, 47(2): 238-254.

DOI: https://doi.org/10.1007/s11747-018-0607-4

Diebner, R., Silliman, E., Ungerman, K., \& Vancauwenberghe, M. 2020. Adapting Customer Experience in the Time of Coronavirus. McKinsey \& Company, April: 1-7. https://www.mckinsey.com/business-

functions/marketing-and-sales/our-

insights/adapting-customer-experience-in-the-time-

of-coronavirus

Ehrlich, O., Fanderl, H., \& Habrich, C. 2017. Mastering the Digital Advantage in Transforming Customer Experience. McKinsey \& Company, 1-6.

https://www.mckinsey.com/business-

functions/operations/our-insights/mastering-thedigital-advantage-in-transforming-customer-

experience

Filip, P., \& Čegan, L. 2019. Comparing Tools for Websession Recording and Replaying. International Conference on Sustainable Information Engineering and Technology (SIET), 257-260.

DOI:

https://doi.org/10.1109/SIET48054.2019.8986134

George, M., \& Wakefield, K.L. 2018. Modeling the Consumer Journey for Membership Services. Journal of Services Marketing, 32(2): 113-125.

DOI: https://doi.org/10.1108/JSM-03-2017-0071

Google. 2018. Understand today's customer journey with Google Analytics.

https://marketingplatform.google.com/about/resour ces/analytics-customer-journey-feature-brief/

Graves, E., Zheng, S., Tarte, L., Levine, B., \& Reddy, A. 2019. Customer Journey Time Metrics for New York City Bus Service using Big Data. Transportation Research Record, 2673(9): 1-10.

DOI: https://doi.org/10.1177/0361198118821632

Grewal, D., \& Roggeveen, A.L. 2020. Understanding Retail Experiences and Customer Journey Management. Journal of Retailing, 96(1): 3-8.

DOI: https://doi.org/10.1016/j.jretai.2020.02.002

Gurumurthy, R., Schatsky, D., \& Camhi, J. 2020. Uncovering the Connection Between Digital Maturity and Financial Performance. Deloitte Insights, 1-20.

Hamilton, R., Ferraro, R., Haws, K. L., \& Mukhopadhyay, A. 2020. Traveling with Companions: The Social Customer Journey. Journal of Marketing, 002224292090822.

DOI: https://doi.org/10.1177/0022242920908227

Hu, T.I., \& Tracogna, A. 2020. Multichannel Customer Journeys and their Determinants: Evidence from motor insurance. Journal of Retailing and Consumer Services, 54.

DOI:

https://doi.org/10.1016/j.jretconser.2019.102022

Inversini, A. 2017. Managing Passengers' Experience Through Mobile Moments. Journal of Air Transport Management, 62: 78-81.

DOI: https://doi.org/10.1016/j.jairtraman.2017.03.009

Kaczorowska-Spychalska, D. 2017. Consumer Perspective of Omnichannel Commerce. Management, 21(2): 95-108.

DOI: https://doi.org/10.1515/manment-2017-0007 


\section{How Can Firms Effectively Use Technology in Customer Journey Management}

\section{William Boscardini Helouani}

Kankainen, A., Vaajakallio, K., Kantola, V., \& Mattelmki, T. 2012. Storytelling Group-a co-design Method for Service Design. Behavior and Information Technology, 31(3): 221-230.

DOI: https://doi.org/10.1080/0144929X.2011.563794

Kim, H., Jiang, J., \& Bruce, N.I. 2020. Discovering Heterogeneous Consumer Journeys in Online Platforms: implications for networking investment. Journal of the Academy of Marketing Science., 49(20): 374-396.

DOI: https://doi.org/10.1007/s11747-020-00741-3

Klein, J.F., Zhang, Y., Falk, T., Aspara, J., \& Luo, X. 2020. Customer Journey Analyses in Digital Media: exploring the impact of cross-media exposure on customers' purchase decisions. Journal of Service Management, 31(30): 489-508.

DOI: https://doi.org/10.1108/JOSM-11-2018-0360

Lemon, K.N., \& Verhoef, P.C. 2016. Understanding Customer Experience Throughout the Customer Journey. Journal of Marketing, 80(6): 69-96.

DOI: https://doi.org/10.1509/jm.15.0420

Lynch, S., \& Barnes, L. 2020. Omnichannel Fashion Retailing: examining the customer decision-making journey. Journal of Fashion Marketing and Management, 24(3): 471-493.

DOI: https://doi.org/10.1108/JFMM-09-2019-0192

Marino, V., \& Lo Presti, L. 2019. Disruptive Marketing Communication for Customer Engagement. The New Frontiers of Mobile Instant Messaging. JMM International Journal on Media Management, 21(1): 323.

DOI: https://doi.org/10.1080/14241277.2019.1590837

Matsuoka, K. 2020. Exploring the Interface Between Management Accounting and Marketing: a literature review of customer accounting. Journal of Management Control, 31(3): 157-208.

DOI: https://doi.org/10.1007/s00187-020-00299-9

McColl-Kennedy, J.R., Zaki, M., Lemon, K.N., Urmetzer, F., \& Neely, A. 2019. Gaining Customer Experience Insights That Matter. Journal of Service Research, 22(1): 8-26.

DOI: https://doi.org/10.1177/1094670518812182

Micheaux, A., \& Bosio, B. 2019. Customer Journey Mapping as a New Way to Teach Data-Driven Marketing as a Service. Journal of Marketing Education, 41(2): 127-140.

DOI: https://doi.org/10.1177/0273475318812551

Mosquera, A., Juaneda-Ayensa, E., Olarte-Pascual, C., \& Pelegrín-Borondo, J. 2018. Key Factors for In-store Smartphone Use in an Omnichannel Experience: Millennials vs. nonmillennials. Complexity, 2018: 114.

DOI: https://doi.org/10.1155/2018/1057356

Mosquera, A., Olarte Pascual, C., \& Juaneda Ayensa, E. 2017. Understanding the Customer Experience in the Age of Omni-Channel Shopping. Revista ICONO14 Revista Científica de Comunicación y Tecnologías Emergentes, 15(2): 92-114.

DOI: https://doi.org/10.7195/ri14.v15i2.1070
Nam, H., \& Kannan, P.K. 2020. Digital Environment in Global Markets: Cross-Cultural Implications for Evolving Customer Journeys. Journal of International Marketing, 28(1): 28-47.

DOI: https://doi.org/10.1177/1069031X19898767

Nyström, A.G., \& Mickelsson, K.J. 2019. Digital Advertising as Service: introducing contextually embedded selling. Journal of Services Marketing, 33(4): 396-406.

DOI: https://doi.org/10.1108/JSM-01-2018-0043

Pallant, J.L., Sands, S., \& Karpen, I.O. 2020. The 4Cs of Mass Customization in Service Industries: a customer lens. Journal of Services Marketing, 34(4): 499-511. DOI: https://doi.org/10.1108/JSM-04-2019-0176

Paluch, S., \& Tuzovic, S. 2019. Persuaded Self-tracking with Wearable Technology: carrot or stick? Journal of Services Marketing, 33(4): 436-448.

DOI: https://doi.org/10.1108/JSM-03-2018-0091

Ramshaw, A. 2016. Customer Journey Mapping Software Review.

https://www.genroe.com/blog/journey-mappingsoftware/11058

Rosenbaum, M.S., Otalora, M.L., \& Ramírez, G.C. 2017. How to Create a Realistic Customer Journey Map. Business Horizons, 60(1): 143-150.

DOI: https://doi.org/10.1016/j.bushor.2016.09.010

Shen, S., Sotiriadis, M., \& Zhang, Y. 2020. The Influence of Smart Technologies on Customer Journey in Tourist Attractions within the Smart Tourism Management Framework. Sustainability (Switzerland), 12(10), 4157. DOI: https://doi.org/10.3390/su12104157

Singh, J., Nambisan, S., Bridge, R.G., \& Brock, J.K.U. 2020. One-Voice Strategy for Customer Engagement. Journal of Service Research, 24(1): 42-64.

DOI: https://doi.org/10.1177/1094670520910267

Sperkova, L. (n.d.). Integration of textual VoC into a CX data model for business intelligence use in B2C. https://ojs.hh.se/

Steward, M.D., Narus, J.A., Roehm, M.L., \& Ritz, W. 2019. From Transactions to Journeys and Beyond: The evolution of B2B buying process modeling. Industrial Marketing Management, 83: 288-300.

DOI:

https://doi.org/10.1016/j.indmarman.2019.05.002

Tax, S.S., McCutcheon, D., \& Wilkinson, I.F. 2013. The Service Delivery Network (SDN): A Customer-Centric Perspective of the Customer Journey. Journal of Service Research, 16(4): 454-470.

DOI: https://doi.org/10.1177/1094670513481108

Teixeira, J., Patrício, L., Nunes, N.J., \& Nóbrega, L. 2011. Customer Experience Modeling: Designing interactions for service systems. Lecture Notes in Computer Science (Including Subseries Lecture Notes in Artificial Intelligence and Lecture Notes in Bioinformatics), 6949 LNCS(PART 4): 136-143.

DOI: https://doi.org/10.1007/978-3-642-23768-3_11 


\section{How Can Firms Effectively Use Technology in Customer Journey Management}

\section{William Boscardini Helouani}

Terragni, A., \& Hassani, M. 2018. Analyzing Customer Journey with Process Mining: from Discovery to Recommendations.

Tupikovskaja-Omovie, Z., \& Tyler, D. 2020. Clustering Consumers' Shopping Journeys: eye-tracking fashion m-retail. Journal of Fashion Marketing and Management, 24(3): 381-398.

DOI: https://doi.org/10.1108/JFMM-09-2019-0195

Voorhees, C.M., Fombelle, P.W., Gregoire, Y., Bone, S., Gustafsson, A., Sousa, R., \& Walkowiak, T. 2017. Service Encounters, Experiences and the Customer Journey: Defining the field and a call to expand our lens. Journal of Business Research, 79(November 2016): 269-280.

DOI: https://doi.org/10.1016/j.jbusres.2017.04.014

Wagner, G., Schramm-Klein, H., \& Steinmann, S. 2020. Online Retailing Across E-channels and E-channel Touchpoints: Empirical studies of consumer behavior in the multichannel e-commerce environment. Journal of Business Research, 107: 256-270.

DOI: https://doi.org/10.1016/j.jbusres.2018.10.048

Wang, R.J.H. 2020. Branded Mobile Application Adoption and Customer Engagement Behavior. Computers in Human Behavior, 106.

DOI: https://doi.org/10.1016/j.chb.2020.106245

Wilson-Nash, C., Goode, A., \& Currie, A. 2020. Introducing the Socialbot: a novel touchpoint along the young adult customer journey. European Journal of Marketing, 54(10): 2621-2643.

DOI: https://doi.org/10.1108/EJM-07-2019-0555

Wong, J., Chiu, M., Duerst, M., Scheibenreif, D., Stewart, B., \& Brand, S. 2021. Top Strategic Technology Trends for 2021 (Issue December 2020).

https://www.gartner.com/document/3994909

Wozniak, T., Schaffner, D., Stanoevska-Slabeva, K., \& Lenz-Kesekamp, V. 2018. Psychological Antecedents of Mobile Consumer Behavior and Implications for Customer Journeys in Tourism. Information Technology and Tourism, 18(1-4): 85-112.

DOI: https://doi.org/10.1007/s40558-017-0101-8

Wozniak, T., Stangl, B., Schegg, R., \& Liebrich, A. (n.d.). The Return on Tourism Organizations' Social Media Investments-Preliminary Evidence from Belgium, France, and Switzerland. Information Technology \& Tourism, 17(1): 75-100.

DOI: https://doi.org/10.1007/s40558-017-0077-4

\section{About the Author}

William Boscardini Helouani, Lic.Sc.(Tech.) is the Latin America IT Director for Customer Experience at Electrolux. He has more than 15 years of working experience in the manufacturing industry in different digital areas, including IT, product, marketing, and ecommerce. Pursuing an M.Sc degree at Sao Paulo School of Business Administration (FGV EAESP), he researches the impact of companies' IT capabilities on the Customer Experience.

Citation: Helouani, W.B. 2021. How Can Firms Effectively Use

Technology in Customer Journey Management. Technology Innovation

Management Review, 11 (7/8): 33-47.

http://doi.org/10.22215/timreview/1455

Keywords: Customer Journey, Customer Experience, Digital

Transformation, Technology Drivers, Managerial Requirements 